\title{
THE POSSIBILITY OF USING INTERNATIONAL PROJECT FINANCING FOR DEFENSE SYSTEMS
}

\author{
Nemanja Pantić \\ Nikola Krunić** \\ Iva Matić***
}

\author{
Достављен: 17. 04. 2020. \\ Језик рада: Енглески \\ Прихваћен: 08. 09. 2020. \\ Tип рада: Прегледни рад \\ DOI број: 10.5937/vojdelo2001056P
}

\begin{abstract}
The term "project financing" is often used to describe all types of project financing, but in recent years it has evolved towards a more precise definition, so that it implies the financing of a particular economic unit in which lenders are comfortable to rely initially on the cash flow and income of these economic units, which the loans will be repaid from, and on the property of that economic unit as collateral for the given loan. Project funds can be adequately used to finance the defense system. They generally fall into the category of development priorities and usually enjoy numerous benefits (primarily tax and customs benefits) provided by the host country of a project, which generally generates more income for participants in project financing than when it comes to conventional credit. The BOT model for financing infrastructure projects has a number of potential benefits and it is an effective alternative in many countries with a more traditional approach to using government borrowing or state budget, with the government retaining strategic control over the project which will become public sector property.
\end{abstract}

Key words: project financing, BOT model, defense system, financial institutions

\footnotetext{
* Nemanja Pantić, Ph.D., Teaching Assistant, University of Kragujevac, Faculty for Hotel Management and Tourism in Vrnjačka Banja, Vojvođanska 5A Street, 36210 Vrnjačka Banja, Serbia, e-mail: nemanja.pantic@kg.ac.rs

** Nikola Krunić, M.A., University of Business Studies Banja Luka, Jovana Dučića 23a Street, 78000 Banja Luka, Bosnia and Herzegovina, e-mail: nikola.krunic@gmail.com

*** Iva Matić, M.A., University of Business Studies Banja Luka, Jovana Dučića 23a Street, 78 000 Banja Luka, Bosnia and Herzegovina, e-mail: ivaamatic@gmail.com
} 


\section{Introduction}

$T^{\text {hetes }}$ he budget as one of the instruments for financing public expenditures is limited, usually on an annual basis. The financing of investment projects requires additional funds, especially for the needs of the defense system, which is increasing from year to year. In this regard, there is a need for additional sources of funding to ensure the maintenance of operational capabilities of the defense system at a satisfactory level.

Project financing is a financing modality that is particularly important and attractive due to the size and complexity of projects that can be financed in this way. It is a very attractive and useful technique used all over the world among various branches of industry. Project financing is a model that has long been in use in developed countries and it is used to maximize results within the available funding. In developing countries, this method of financing infrastructure projects is certainly present in the broadest sense, but it is expected to gain its importance, since developing countries generally do not have sufficient financial resources to launch large projects, that is, to complement them in the right way. Project financing is defined as the financing of a particular project, most often infrastructure or industrial one, with lenders relying on the cash flow and project revenues as sources of funds to repay the invested funds. This basically means that the investor has an insight into the cash flows, and that the realized profit is the only way to return the invested funds, that is, the project assets should provide financing for the project itself, and in that sense it is the only guarantee for the execution of this project. The driving force behind project financing is its sponsors and investors. The project sponsor is the party behind the project, who makes it the driving force, most often the government of a country, an independent entity of a business sector or a consortium, the future buyer of the project's products or services. The project financiers are mainly financial institutions such as international development finance organizations, banks, investment funds, equipment manufacturers, contractors, future buyers, etc. The BOT model is the most widely used model of infrastructure project financing. Basically, it implies all forms of investment in public infrastructure, where the financing and risk of business failure is assumed by a private company. It does so on the basis of a concession obtained by a state or local government for the construction and management of an infrastructure facility. On the other hand, the BOT model of private financing of an infrastructure project implies the totality of all organizational, technical, economic and legal activities that are necessary for its implementation. It is legally expressed in the contract for financing the infrastructure project. ${ }^{1}$ Although created earlier, the end of the twentieth century was the period of its full affirmation, especially in developing countries. However, its implementation in developed countries is not insignificant. The BOT model of private financing of infrastructure projects is used in various fields for various infrastructure projects such as power plants, roads,

\footnotetext{
${ }^{1}$ Ivan Milojević and Milan Mihajlović, "Primena metoda ocene investicionih projekata u javnom sektoru”, Oditor - časopis za Menadžment, finansije i pravo, Vol. 5, No. 1, 2019, pp. 19-31.
} 
bridges, tunnels, water supply facilities, etc. As a rule, these are projects of great importance and value, not only nationally. On the other hand, this legal instrument can also be used for the needs of infrastructure construction within the defense system, having in mind its needs and complexity. In addition to differences in relation to projects in other areas, it should be mentioned that there are certain similarities and even complete identities in certain types of projects. This primarily refers to construction projects such as the construction of various buildings, bridges, airports, fortifications, protective spaces and rooms, etc.

\section{A theoretical overview of project financing}

Although the term project financing (project finance) is often used to describe all types of project financing, the term has evolved in recent years towards a more precise definition, so that it implies financing a particular economic unit where lenders are comfortable to rely initially on the cash flow and income of these economic units as a source of funds, which the loans will be repaid from, and on the assets of that economic unit as collateral for the loan. ${ }^{2}$ In doing so, the authors of this definition emphasize that the keyword is initial, as lenders may initially be willing to observe the cash flow of the project as a source of loans repayment, but also have to consider that the loans will actually be repaid in the worst case scenario. This includes obligations and direct or indirect guarantees from the third parties. For the purpose of this definition, a project means an economic unit capable of generating sufficient cash flow to cover operational costs and service debt by conservative standards for a reasonable period of time shorter than the economic life of the project assets. ${ }^{3}$ Other definitions may be encountered in the professional literature, but they also basically boil down to project financing being considered a financial modality, where lenders (creditors) rely on project cash flows as a source for debt repayment and project assets as security for it. ${ }^{4}$

Project financing is connected with off-balance sheet financing, since it uses the third party funds to finance a particular project, and the debt on this basis does not directly affect the balance sheet of the project owner or project sponsor. ${ }^{5}$ It is noted that there is a widespread (wrong) interpretation that project financing means offbalance sheet financing to such an extent that the project is self-financing (self-supporting) without any guarantees and obligations from other persons (financially responsible).

\footnotetext{
${ }^{2}$ Roman Gorshkov and Viktor Epifanov, „The Mechanism of the Project Financing in the Construction of Underground Structures", Procedia Engineering, Vol. 165, No. 2, pp. 1211-1215.

${ }^{3}$ Nevitt, P. K. \& Fabozzi, F. (1983). Project Financing (Sixth Edition), Euromoney Publications, London. p. 361.

${ }^{4}$ UNIDO (1996). Guidelines for Infrastructure Development through Build-Operate-Transfer Projects, Vienna, p. 295.

5 João M. Pinto, „What is project finance?", Investment Management and Financial Innovations, Vol. 14, No. 1, 2017, pp. 200-210.
} 
Project financing is also called structured financing in some cases because it requires such structuring (combining) of debt and equity (referring to the capital of the project owner and/or sponsor), so that the cash flow of the project can adequately service the debt project. $^{6}$ In any case, the key to successful project financing is to structure the project financing so that it has as little recourse as possible from the sponsor, while providing sufficient credit support to the project through the obligations or guarantees of the sponsor or third parties so that lenders are satisfied with the credit. ${ }^{7}$ The basic elements of a project financing model are that:

1 ) it is a way of financing projects, mostly one of the higher value;

2) this funding is predominantly based on the provision of external sources of financing, and to a lesser extent on the capital of the sponsor or the project owner himself (although it can be very significant in absolute terms depending on the project);

3 ) the financing creditors, when deciding to invest in the project, initially and primarily view the future cash flows and incomes of the (completed) project as a source of funds to repay its debt, and the project assets as security to repay this debt;

4) there does not exist, or is limited, the creditor's right of recourse to sponsors (project owners, the third parties) in the case of default on the project's debt obligations (which is generally a higher case);

5) through the obligations or guarantees of the sponsor or third parties, the credit risk of the project appears acceptable to its creditors - financiers;

6 ) the ultimate goal of project financing is to arrange project financing that will benefit the project sponsors, that is, the project owners, and at the same time that financing does not affect their credit rating and balance.

Project finance understood in this way is not a specific, unknown instrument so far, but its specificity in relation to the classical way of financing projects is that the immediate financial obligations of the sponsor or the project owner are much smaller, and the aim is to carry as much debt as possible the project itself appears. ${ }^{8}$ This implies that projectswhich can be implemented on this basis have to be sufficiently financially viable to generate enough funds from the operational phase to cover the operational costs of the project, to meet all debt obligations and to bring sponsors or owners the corresponding benefits (profit) to the capital they have directly invested.

In traditional corporate financing (corporate finance), external finance lenders rely on the total creditworthiness, that is, the overall balance of the company financing a project as a source of debt repayment funds, not just a specific project financed from those assignments. Here, the company is the sole debtor and owner of the project and it is responsible for the obligations assumed with all its assets and bears all the risk of the project's execution and success. Otherwise, a company can mobilize

\footnotetext{
${ }^{6}$ UNIDO (1996). Guidelines for Infrastructure Development through Build-Operate-Transfer Projects, Vienna, p. 295.

${ }^{7}$ Milka Grbić and Dejan Jovanović, „Komparativni finansijski sistemi: implikacije za ekonomski rast", Oditor - časopis za Menadžment, finansije i pravo, Vol. 6, No. 1, 2020, pp. 49-65.

${ }^{8}$ Mansoor Dailami and Danny Lepiziger, "Infrastructure Project Finance and Capital Flows: A New Perspective", World Development, Vol. 27, No. 7, 1998, pp. 1283-1298.
} 
funds for the execution of a particular project in many ways from the issue of shares (recapitalization) and debt securities (bonds) in the capital market, through taking loans and other forms of borrowing. In this case, the defense system has no additional obligations during the implementation of such projects, but the responsibility lies solely with the company that invests the funds.

\section{Participants in project financing}

The main participants in project financing are project sponsors and funders. The project sponsor is the party behind the project and is its driving force. It may be the government of the host country of a project, which, by its execution, achieves some national or development goals. ${ }^{9}$ This may be an independent private sector entity or a consortium (for example, a contractor), or it may be a prospective buyer (from the private or public sector) of the project's products or services. For the sponsor or project owner, the key to some benefit is the execution of the project and for that purpose he is willing to take an entrepreneurial risk to a different extent, directly or indirectly, but endeavors to keep this engagement as much as possible. It is also necessary to transfer as much of the funding burden (and risk) as possible to other sources of funds. The project sponsor may also appear as a project developer who develops the project, with the aim of bringing it to the stage of eligibility for funding and execution.

The role of project financier, in various forms, can involve a wide range of participants: banks (foreign and national), financial companies, investment funds, institutional investors, international development financing banks, local development financing banks, export credit agencies, equipment manufacturers, contractors, buyers of future project production services, etc. Their motives are very different, ranging from the classic granting of interest-rate loans as the price of capital, to securing placement or sources of supply, to broader national and development goals.

The involvement of private project sponsors and sector financiers generally assures the host country government that the project is economically and financially healthy and will contribute directly and/or indirectly to the overall well-being of the country, that is, to meet certain needs. ${ }^{10}$ From the aspect of international financing of investment projects, however, the most important advantage that project financing alone offers to a whole range of developing and transition countries with or without a lower credit rating in terms of the access to the international capital market, in the context of bilateral public assistance for development is limited and the resources of international financial organizations are insufficient to meet these needs.

\footnotetext{
${ }^{9}$ Stefan Milosavljević, Đorđe Pantelejić i Damir Međedović, "Primena i mogućnost unapređenja ekonomskih činilaca u realizaciji održivog razvoja", Održivi razvoj, Vol. 1, No. 1, 2019, pp. 7-14.

${ }^{10}$ Daniela Klingbel and Jeff Ruster, "Why Infrastructure Facilities Often Fall Short of Their Objectives", World Bank Group, https://elibrary.worldbank.org/doi/abs/10.1596/1813-9450-2358, 26/02/2018, pp. 8.
} 
As it has already been noted, project sponsors and funders can come from both the public and private sector. Strengthening the link between the two sectors and pooling their resources as part of the implementation of major infrastructure and other investment projects nationally and internationally is one of the important features of contemporary economic development in a whole range of countries, especially developed countries, where institutional capacities are greater.

Project-based facilities generally fall into the category of development priorities and usually enjoy many benefits (first and foremost, tax and customs benefits) granted by the host country, and thus generally provide greater revenue for participants in project finance than when it comes to classic credit. Since the project is funded and not sponsored by the project or the host country government, project financiers generally have a clear cost calculation, thus avoiding the possibility of the project sponsor or government transferring its costs on other grounds to the project.

Significant participants in project financing are the project company and a consortium of contractors or some other form of their business organization. The project company is formed as a legal entity that is the bearer of activities for the execution of the project and it is also the mechanism through which its financing is conducted, and in the later stages, the operational management of the project. The founders of the project company are mainly sponsors or project owners, who provide the initial (founding) capital for its business and project development. Investment in the core capital of the project company (and practically the project's own capital) can also be made by contractors, equipment suppliers, host country governments, international and national development financing institutions, users of future project products and/or services, or anyone who sees it. Some are interested and therefore willing to take an entrepreneurial risk through investment in venture capital. ${ }^{11}$ A consortium of contractors (and equipment suppliers) is mainly organized as a business contracting arrangement for large and complex projects, to consolidate their activities in the pre-investment phase, which should result in the submission of a joint bid and the conclusion of the contract (for the construction of the facility, and possibly its operational management upon completion of the construction phase). In the event of the conclusion of the contract, the consortium may retain the existing contractual regulation of the relations of participants in the business, or (whichever is the higher) to form a project company that institutionally consolidates activities on the execution of the project.

Project financing has two key advantages over the conventional way of financing projects for all participants. ${ }^{12}$ Firstly, it increases the availability of funding sources, thus enabling the execution of a project that, due to the size of the investment required, would not be carried out solely on the basis of the project sponsor's own equity or direct debit (bank loans and capital markets). Secondly, risk is reduced, i.e. allocated to project finance participants, and experience has shown that adequate risk allocation to project participants is a very important factor in the initiation and success of each project.

\footnotetext{
11 John Mawutor and Kwadwo Obeng, „The Role of Project Finance in Contemporary Financing: "Theoretical Perspective", Accounting and Finance Research, Vol. 3, No. 4, 2014, pp. 181-185.

12 Jakob Müllner, „International project finance: review and implications for international finance and international business“, Management Review Quarterly volume, Vol. 67, No. 1, 2017, pp. 97-133.
} 


\section{The distribution of project financing in the world}

The globalization of international trade and finance in recent decades has significantly contributed to the development of project finance worldwide. However, it is not equally present in all countries, regions and sectors. ${ }^{13}$ Project financing is relatively most prevalent in developed industrialized countries and more developed among developing countries and countries in transition. In terms of individual sectors, project finance is relatively most represented in transport, energy, telecommunications and water management. ${ }^{14}$ Otherwise, project financing is mainly related to the implementation of large infrastructure facilities, although virtually any investment project can be implemented on its principles, of course, taking into account its specificities.

When considering the spread of project financing in the world, the problem arises in the domain of the available statistical basis, since only major arrangements of this kind are generally registered. Another problem is that not all relevant terms of the project finance arrangement are always available to the public, since they are in the realm of trade secrets that neither sponsors nor financiers are willing to fully present.

Table 1 - Long-term liabilities by region (in millions of USD)

\begin{tabular}{|c|c|c|c|c|c|}
\hline Region & 2013 & 2014 & 2015 & 2017 & 2018 \\
\hline East Asia and the Pacific & 2873 & 2771 & 2288 & 1738 & 1940 \\
\hline Europe and Central Asia & 3261 & 3478 & 1534 & 2084 & 2256 \\
\hline Latin America and the Caribbean & 4822 & 4057 & 2379 & 2693 & 2509 \\
\hline Central, Eastern and North Africa & 2038 & 1698 & 893 & 951 & 1010 \\
\hline Sub-Saharan Africa & 3501 & 3540 & 1831 & 2323 & 1566 \\
\hline South Asia & 1697 & 1558 & 1402 & 1982 & 2080 \\
\hline General & 156 & 158 & 212 & 84 & 268 \\
\hline In total & 18348 & 17260 & 10539 & 11855 & 11629 \\
\hline
\end{tabular}

Source: Adapted by the author according to IFC - International Finance Corporation World Bank Group, https://disclosures.ifc.org/\#/landing

A look at Table 1 and long-term commitments by region show that they are the largest in Latin America and the Caribbean, followed by Europe and Central Asia.

${ }^{13}$ Slobodan Vladušić, „Strategic culture and images of wars from the last decade of 20th century in Serbian prose“" Vojno Delo, Vol. 71, No. 8, 2019, pp. 155-165.

${ }^{14}$ Suzana Mićović i Jovana Miletić, "Poslovni subjekt kao osnova održivosti razvoja", Održivi razvoj, Vol. 1, No. 1, 2019, pp. 41-49. 
After them, Asia stands out in terms of long-term liabilities. Looking at the period 2013-2018, their decrease is noticed at the end of the observed period compared to its amount at the beginning, except in the case of South Asia, where there was an increase in long-term liabilities.

Table 2 - Total number of published projects by region in the period 1994-2018.

\begin{tabular}{|l|r|}
\hline East Asia and the Pacific & 889 \\
\hline Europe and Central Asia & 1235 \\
\hline Latin America and the Caribbean & 1287 \\
\hline Central, Eastern and North Africa & 588 \\
\hline Sub-Saharan Africa & 1277 \\
\hline South Asia & 700 \\
\hline The world & 259 \\
\hline \multicolumn{2}{|c|}{ In total } \\
\hline
\end{tabular}

Source: Adapted by the author according to IFC - International Finance Corporation World Bank Group https://disclosures.ifc.org/\#/landing

From the above-mentioned data it can be seen that more than half (number and value) of the concluded project financing arrangements were in developing countries, mainly in Asia, Africa and Latin America.

The Asian financial crisis has also led to the crisis of new mega projects in these countries, but has also given foreign investors the opportunity to reconsider project financing for small and medium-sized projects in developing countries, which have long been overshadowed by mega projects. Many international financial institutions, even the EU, have included project financing for small and medium-sized projects in their priorities. ${ }^{15}$

Otherwise, there is no unique database of concluded project financing arrangements. ${ }^{16}$ Thus, according to Project Finance Review, global project finance loans in the first quarter of 2018 amounted to $\$ 39.8$ billion from 143 projects, down to $30.8 \%$ from the previous quarter over the same period last year and the smallest first quarter volume of 2012 . The energy sector reached $\$ 16.3$ billion and accounted for $40.8 \%$ of the activity market, despite a $52.1 \%$ decline from the first quarter of 2017.

${ }^{15}$ Stanimir Đukić, „Analysis of the specificity of the source of corruption and the security of society“, Vojno delo, Vol. 71, No. 4, 2019, pp. 156-171.

${ }^{16}$ Bratislav Stanković, Radovan Damnjanović i Milenko Popović, "Forms of public expenditure supervision", Oditor - časopis za Menadžment, finansije i pravo, Vol. 4, No. 3, 2018, pp. 96-109. 


\section{BOT project finance model}

BOT is a term for a model or construction that uses private investment to develop infrastructure, which was previously reserved for the public sector. Project financing is a cornerstone of the BOT approach, as financiers view project assets and project revenue inflows as a source of repayment of invested funds, more than other types of collateral, such as government guarantees or project sponsor assets.

In a BOT project, a private company is given a concession to build and run a facility that would normally be built and run by the government. That facility may be a power plant, an airport, a toll highway, a tunnel or a water treatment plant. The private company is also responsible for designing and financing the project, and at the end of the concession period, the private company transfers ownership of the project to the government, although this may not always be the case. ${ }^{17}$ The concession period is determined primarily by the length of time it takes for the inflow of project revenue to pay off the company's debt and to provide a reasonable profit margin for its efforts and risk.

BOT is a contractual arrangement where a private sector entity assumes the construction of a particular infrastructure facility including design and financing, as well as its maintenance and use after construction. The private sector entity manages the facility for a specified period of time in which it is allowed to charge users appropriate fees and other costs not exceeding the level proposed in the tender and established by the project arrangement, which enables the private sector entity to repay the investment in the construction of the facility, as well as to cover the costs of maintaining and operating the facility including reasonable profits. ${ }^{18}$

At the end of the designated period, the private sector entity hands over the facility to a government agency or new private entity selected through a public auction. BOT is a form of privatized project development, where the government grants a concession of limited duration to private sector sponsors to set up a project, hold an ownership position in it, arrange for it to be financed by the third parties and manage the project for the duration of the concession. In general, the duration of the concession is shorter than the economic lifetime of the facility (for a coal-fired power station, the operating lifetime of the concession is usually 15-20 years, as opposed to the economic life of the plant, which is $30-40$ years). Usually, project ownership is transferred to the government free of charge, as project sponsors have been able to obtain an agreed rate of return during the concession as compensation for their capital investment.

${ }^{17}$ Milan Mihajlović, Snežana Krstić, Slobodan Šegrt, Dragana Pavlović, Duško Jovanović and Tihomir Simeunović, "Economic analysis of the influence of milk market concentration on procurement efficiency in the defense system", Economics of Agriculture, Vol. 63, No. 3, 2016, pp. 973-986.

18 Jelena Matijašević Obradović i Ivan Jokšić, „Oblici privrednog kriminaliteta u bankarskom poslovanju“, Vojno delo, Vol. 71, No. 6, 2019, pp. 49-58

${ }^{19}$ Karl Jechoutek and Ralph Lemech, "Private Power Financing - From Project Finance to Corporate Finance", Public Policy for the Private Sector, No. 56, https://www.worldbank.org/, 15/05/2018, pp. 8. 
In the broadest sense, a BOT job involves attracting an international consortium (foreign investors) to finance all costs and execution of project, construction and assembly works, exploitation and technical servicing of the facility, by contracting or securing a way to recover the invested capital and to obtain appropriate profit.Upon expiration of the agreed period, the leased property shall be taken over by the grantor, without any payment. ${ }^{20}$

BOT is an investment model that finances a particular project - the construction of a facility that, as a rule, encompasses all stages - from concept to physical execution, i.e. construction and equipping. The home side enables the foreign investor to construct the facility at its own cost, organize its operation and use it for a certain period, and after that time, transfer the ownership of the facility to a particular national entity. BOT is a variant of public-private partnerships, stemming from the very nature of this collaboration, which aims to design, build, finance, operate and maintain infrastructure.

The term BOT itself originated from the initial letters of the English words build, operate (manage, lead) and transfer, and is used mainly as a consolidated term for this project financing model, which has several different modalities. ${ }^{21}$

In any case, the basic features of the BOT model are that the public sector (government, state agency, public company, etc.) entrusts (reconstructs, modernizes) a particular facility (usually a higher value infrastructure facility) to the private sector (project sponsors, project company), which is under a contractual arrangement, to fully implement and finance this project, and subsequently to maintain the facility for a specified period (usually 10-30 years) through the payment of products and services of the facility to end users during that period, return the invested capital and make some profit, and at the end of the contract period hand over the facility in proper condition without compensation to the public sector.

This can be especially used in the defense system for the construction of an airport, bearing in mind that many of them were destroyed during the NATO aggression, where the concession would provide use by a company that is the project holder, and after that time the infrastructure would be used by the Serbian Armed Forces.

\section{Phases of the implementation of the BOT model}

The implementation stages of the BOT model are essentially no different from the standard implementation stages of investment projects, with UNIDO dividing them into project identification, government preparation for bidding in its publication dedicated to BOT projects, sponsors' preparation for bidding, selection, project development, project implementation, operational phase and transfer, as shown in the following Table.

\footnotetext{
${ }^{20}$ Branislav Milosavljević, „Obaveštajna komponenta Ministarstva spoljnih poslova i strateška kultura Srbije“, Vojno Delo, Vol. 71, No. 8, 2019, pp. 134-154.

${ }^{21}$ Snežana Topalović and Veljko Marinković, „A multidimensional approach to the analysis of perceived value in tourism",Hotel and Tourism Management, Vol. 8, No. 1, 2020, pp. 49-58.
} 
Table 3 - Phases of BOT projects

\begin{tabular}{|c|c|c|}
\hline No. & Phase & Activity description \\
\hline 1. & Project identification & $\begin{array}{l}\text { Project identification } \\
\text { Defining the form of financing } \\
\text { Preliminary feasibility study } \\
\text { Designation of project manager and project team }\end{array}$ \\
\hline 2. & $\begin{array}{l}\text { Preparing the Government } \\
\text { for a bid }\end{array}$ & $\begin{array}{l}\text { Procurement procedure } \\
\text { Pre-qualification } \\
\text { Project agreement } \\
\text { Tender documentation } \\
\text { Criteria for evaluation of bids }\end{array}$ \\
\hline 3. & Preparing sponsors for a quote & $\begin{array}{l}\text { Formation of consortium/possibly project } \\
\text { company } \\
\text { Feasibility study } \\
\text { Identification of potential partners } \\
\text { Bid submission }\end{array}$ \\
\hline 4. & Choice of the bidder & \begin{tabular}{|l|} 
Bid evaluation \\
Classification of bids \\
Project assignment \\
\end{tabular} \\
\hline 5. & Project development & $\begin{array}{l}\text { Formation of a project company } \\
\text { Sponsor contributions to company capital } \\
\text { Credit arrangements } \\
\text { Closing financial construction } \\
\text { Construction works contract } \\
\text { Delivery contract for equipment and materials } \\
\text { for the project } \\
\text { Project product takeover agreement } \\
\text { Insurance contract } \\
\text { Project maintenance and management } \\
\text { agreement }\end{array}$ \\
\hline 6. & Project implementation & $\begin{array}{l}\text { Construction of the facility and installation of } \\
\text { equipment } \\
\text { Testing - trial } \\
\text { Reception of the object } \\
\text { Technology transfer and workforce training } \\
\text { Project evaluation }\end{array}$ \\
\hline 7. & $\begin{array}{l}\text { The operational phase of the } \\
\text { project }\end{array}$ & $\begin{array}{l}\text { Management and maintenance in the concession } \\
\text { period } \\
\text { Inspections } \\
\text { Technology transfer and workforce training }\end{array}$ \\
\hline 8. & Transfer of the project & Transfer procedure \\
\hline
\end{tabular}

Source: UNIDO (1996), Guidelines for Infrastructure Development through Build-Operate-Transfer (BOT) Projects, Vienna, pp. 22. 
The specificity of the project cycle according to the BOT model in relation to classical investment projects is reflected mainly in the operational phase and the transfer phase. With the implementation of classical investment projects for contractors, the work is completed by handing over the facility to the investor (with a possible subsequent period covered by obligations under the guarantees for works and equipment). However, for a project company according to the BOT model, that is, for project sponsors, only then the real part of the work begins. In the operational phase established by the project arrangement, the project company manages the project/facility, either directly or through an engaged operator, and from the inflow of income from the project/facility exploitation, settles the project operational costs, servicing the liabilities to the creditors and returning the invested capital of the sponsor, with appropriate profit. The host country government is usually entitled to inspect the operation of the facility at the operational stage. ${ }^{22}$

The final phase of the BOT model project cycle is the transfer of the project/facility to the host country government at the end of the contracted period. As a rule, BOT projects are such that they allow project sponsors to repay project debt, recover capital and make profits, so that the transfer of the project to the host country government is only of a nominal nature. The interest of the host country government is only to ensure during the transfer that the project/facility is adequately maintained and in proper condition and that technology transfer and staff training have been carried out, so that it can continue to operate.

Depending on the determination of the host country government, the project sponsor or project company may continue to use the facility under a new arrangement or this right may be granted to a new operator based on a bid or the facility will be transferred to the public sector.

\section{Conclusion}

Maintaining the operational capabilities of the defense system is the task of each state, but the available financial resources are limited, so it is necessary to seek new sources of funding. Project financing can be an attractive financing model for large projects that can survive as an independent economic unit, that is, when sponsoring companies are sensitive to the use of debt in the function of project financing and the risk that accompanies project implementation. It is notable that project finance is particularly suitable when businesses would like to maintain operational control of the project, accept complex contracts, firm commitments and strong financial controls that, by nature, follow project financing as a financing modality. Project financing arrangements involve a common interest between the different parties and, ac-

\footnotetext{
${ }^{22}$ Antonio Estache and John Strong, "The Fall, andthe Emerging Recovery of Project Finance in Transport", The World Bank, Working Paper, No. 2385, https://ideas.repec.org/p/wbk/wbrwps/2385.html, 25/03/2019, pp. 5.
} 
cordingly, the expected economic return of each participant is commensurate with the risk they incur in carrying out the project. Project finance provides a number of advantages over direct corporate-based financing. Potential benefits are only possible after a careful analysis of professional financial engineering. The project organization, its legal structure, as well as its financial plan should reflect the nature of the project, the identified project risk, profitability, creditworthiness of participants, tax credits, sponsor and state financial position, as well as other factors that significantly affect the desire of potential investors and lenders. Project financing allocates risk and return relative to direct corporate financing more successfully, and contracts that accompany project financing are designed to allocate project risk and return in the most appropriate way, according to the capabilities of participants in the project implementation. That is why project financing allows to minimize credit impact on project sponsors, and contracts that support project loans are formed in such a way as to minimize direct financial commitment of project sponsors. The BOT financing model is extremely complex, not only because of its large number of participants, but also because it is a model of pooling different sources of financing for the implementation of crucial infrastructure projects that are at the level of individual entities and even the state, especially now in the course of the global financial and economic crisis, unattainable. It is its importance that enables the execution of high value projects such as highways, bridges, tunnels, etc., which are of great importance for the development of a country and a region. The fact that the BOT model in the implementation and exploitation of public infrastructure projects gives primacy to private capital has led to a higher degree of efficiency in managing public goods with a positive impact at both the micro and macro economic levels. In this case, practice has shown that it goes a few steps ahead of theory and that such a model deserves to be specifically regulated.

\section{Literature}

[1] Antonio Estache and John Strong, "The Fall, andthe Emerging Recovery of Project Finance in Transport", The World Bank, Working Paper, No. 2385, https://ideas.repec.org/p/wbk/wbrwps/2385.html, 25/03/2019, pp. 5.

[2] Branislav Milosavljević, „Obaveštajna komponenta Ministarstva spoljnih poslova i strateška kultura Srbije“, Vojno Delo, Vol. 71, No. 8, 2019, pp. 134-154.

[3] Bratislav Stanković, Radovan Damnjanović and Milenko Popović, "Forms of public expenditure supervision", Oditor - časopis za Menadžment, finansije i pravo, Vol. 4, No. 3, 2018, pp. 96-109.

[4] Daniela Klingbel and Jeff Ruster, "Why Infrastructure Facilities Often Fall Short of Their Objectives", World Bank Group, https://elibrary.worldbank.org/doi/abs/10.1596/1813-9450-2358, 26/02/2018, pp. 8.

[5] Ivan Milojević i Milan Mihajlović, "Primena metoda ocene investicionih projekata u javnom sektoru", Oditor - časopis za Menadžment, finansije i pravo, Vol. 5, No. 1, 2019, pp. 19-31. 
[6] Jakob Müllner, „International project finance: review and implications for international finance and international business", Management Review Quarterly volume, Vol. 67, No. 1, 2017, pp. 97-133.

[7] Jelena Matijašević Obradović i Ivan Jokšić, „Oblici privrednog kriminaliteta u bankarskom poslovanju“, Vojno delo, Vol. 71, No. 6, 2019, pp. 49-58.

[8] João M. Pinto, „What is project finance?“, Investment Management and Financial Innovations, Vol. 14, No. 1, 2017, pp. 200-210.

[9] John Mawutor and Kwadwo Obeng, „The Role of Project Finance in Contemporary Financing: "Theoretical Perspective", Accounting and Finance Research, Vol. 3, No. 4, 2014, pp. 181-185.

[10] Karl Jechoutek and Ralph Lemech, "Private Power Financing - From Project Finance to Corporate Finance", Public Policy for the Private Sector, No. 56, https://www.worldbank.org/, 15/05/2018, pp. 8.

[11] Mansoor Dailami and Danny Lepiziger, "Infrastructure Project Finance and Capital Flows: A New Perspective", World Developmet, Vol. 27, No. 7, 1998, pp. 1283-1298.

[12] Milan Mihajlović, Snežana Krstić, Slobodan Šegrt, Dragana Pavlović, Duško Jovanović and Tihomir Simeunović, "Economic analysis of the influence of milk market concentration on procurement efficiency in the defense system", Ecomomics of Agriculture, Vol. 63, No. 3, 2016, pp. 973-986.

[13] Milka Grbić i Dejan Jovanović, „Komparativni finansijski sistemi: implikacije za ekonomski rast“, Oditor - časopis za Menadžment, finansije i pravo, Vol. 6, No. 1, 2020, pp. 49-65.

[14] Project Finance Review, www.projectfinancereview.com

[15] Roman Gorshkov and Viktor Epifanov, „The Mechanism of the Project Financing in the Construction of Underground Structures", Procedia Engineering, Vol. 165, No. 2, pp. 1211-1215.

[16] Slobodan Vladušić, „Strategic culture and images of wars from the last decade of 20th century in Serbian prose“, Vojno Delo, Vol. 71, No. 8, 2019, pp. 155-165.

[17] Snežana Topalović and Veljko Marinković, „A multidimensional approach to the analysis of perceived value in tourism",Hotel and Tourism Management, Vol. 8, No. 1, 2020, pp. 49-58.

[18] Stefan Milosavljević, Đorđe Pantelejić i Damir Međedović, "Primena i mogućnost unapređenja ekonomskih činilaca u realizaciji održivog razvoja”, Održivi razvoj, Vol. 1, No. 1, 2019, pp. 7-14.

[19] Stanimir Đukić, „Analysis of the specificity of the source of corruption and the security of society“, Vojno delo, Vol. 71, No. 4, 2019, pp. 156-171.

[20] Suzana Mićović i Jovana Miletić, "Poslovni subjekt kao osnova održivosti razvoja”, Održivi razvoj, Vol. 1, No. 1, 2019, pp. 41-49.

[21] UNIDO (1996). Guidelines for Infrastructure Development through BuildOperate-Transfer Projects, Vienna, 295. 


\section{Могућност коришћења међународног пројектног финансирања за потребе система одбране}

зраз „пројектно финансирање” често се користи за описивање свих врста финансирања пројеката, али последњих година се развио ка прецизнијој дефиницији, тако да подразумева финансирање одређене економске јединице у којој су зајмодавци у могућности да се поуздају у готовину протока и прихода ових економских јединица од кога ће се кредити враћати, а на имовини те економске јединице као обезбеђење за дати кредит. Средства пројекта могу се адекватно користити за финансирање система одбране. Пројектна средства уопштено спадају у категорију развојних приоритета и обично уживају бројне погодности (пре свега пореске и царинске олакшице) које пружа држава домаћин пројекта, а који генерално доносе више прихода за учеснике у финансирању пројеката него када је реч о конвенционалним кредитима. Модел БОТ за финансирање инфраструктурних пројеката има бројне потенцијалне користи и ефикасна је алтернатива у многим земљама са традиционалнијим приступом коришћењу државног задуживања или државног буџета, а влада задржава стратешку контролу над пројектом који ће постати власништво јавног сектора.

Кључне речи: пројектно финансирање, БОТ модел, одбрамбени систем, фонансијске институције 